\title{
Perbandingan Stereotipe Gender dalam Iklan: Kajian Semiotika Roland Barthes
}

\author{
Luly Zahrotul Lutfiyah ${ }^{1}$, Kingkin Puput Kinanti ${ }^{2}$, \\ IKIP Budi Utomo Malang ${ }^{1}$, IKIP Budi Utomo Malang ${ }^{2}$ \\ $\underline{\text { zahrotullulyemail@gmail.com }}^{1}$, kinantipuput8@gmail.com ${ }^{2}$
}

DOI: https://doi.org/10.32528/bb.v5i12.3349

First received: 22-06-2020

Final proof received: 25-09-2020

\begin{abstract}
ABSTRAK
Artikel ini membahas mengenai stereotipe gender dalam iklan yang diteliti dengan pendekatan deskriptif kualitatif. Penelitian semiotika mencoba mengkaji fenomena yang ada dalam masyarakat dengan menggunakan simbol baik yang bersifat verbal maupun nonverbal. Penelitian ini bertujuan untuk mengetahui perbandingan stereotipe gender pada dua iklan yaitu iklan kecap $\mathrm{ABC}$ dan Iklan extra joss atau iklan masa kini dengan iklan pada era 5 tahun sebelumnya. Citra perempuan masa lalu digambarkan sebagai perempuan yang menduduki second class dimana kedudukan perempuan di bawah laki-laki. Namun, perkembangan budaya dan pola pikir cenderung menggeser citra tersebut. Penelitian ini akan menggunakan dua iklan yaitu iklan masakan kecap ABC versi Suami bisa masak" dan iklan minuman extra jos versi Laki". Data dibagi menjadi dua yaitu data verbal dan data nonverbal. Teknik pengumpulan data dilakukan dengan dokumentasi dan observasi. Dokumentasi dilakukan dengan metode simak dan catat. Peneliti akan mengumpulkan data kedua iklan kemudian dilakukan teknik simak dan catat. Setelah dilakukan simak dan catat dilakukan analisis dengan menggunakan analisis semiotik Roland Barthes. Analisis juga menggunakan FGD untuk memantapkan hasil penelitian. Penyajian data dilakukan secara informal yaitu menggunakan kata-kata yang mudah dipahami. Hasil penelitian menunjukkan bahwa terjadi pergeseran strereotipe gender antara iklan Extra Joss yang tayang pada tahun 2013 dengan iklan Kecap ABC yang tayang pada tahun 2018. Perbedaan tersebut terdapat pada penggambaran karakter dan peran laki- laki dan perempuan.
\end{abstract}

Kata kunci: stereotipe gender; iklan; semiotika; media massa

\begin{abstract}
This article discusses gender stereotypes in advertisements examined using a qualitative descriptive approach. Semiotics research tries to examine phenomena that exist in society by using symbols that are both verbal and nonverbal. This study aims to determine the comparison of gender stereotypes in two advertisements, namely $\mathrm{ABC}$ soy sauce ads and extra- joss ads or advertisements today with ads in the era of the
\end{abstract}


previous 5 years. The image of women from the past is described as women who occupy the second class where the position of women is below men. However, the development of culture and mindset tends to shift the image. This research will use two advertisements, namely ABC version of Husband's soy sauce cuisine ad can cook "and male version of extra-jos beverage ads". Data is divided into two namely verbal data and nonverbal data. Data collection techniques are done by documentation and observation. Documentation is done by listening and note-taking. Researchers will collect the data of the two advertisements and then consider and record techniques. After examining and recording, an analysis was conducted using Roland Barthes's semiotic analysis. The analysis also uses FGD to solidify the results of the study. Presentation of the data is done informally using words that are easily understood. The results of the study indicate that there is a shift in gender stereotypes between Extra Joss ads that aired in 2013 with ABC Ketchup ads that aired in 2018. These differences are found in the depiction of male characters and roles men and women.

Keywords: gender stereotypes; advertising; semiotics; mass media

\section{METODE PENELITIAN}

Pendahuluan harus memuat latar belakang penelitian, signifikansi penelitian, dan isu-isu yang diangkat dalam penelitian. Media massa merupakan salah satu agen sosialisasi yang sangat berpengaruh terhadap kehidupan masyarakat. Light, Keller dan Calhoun (dalam Sunarto, 2004:26) menyatakan bahwa media massa yang terdiri dari media cetak (surat kabar, majalah) maupun elektronik (radio, televisi, film, internet) merupakan bentuk komunikasi yang menjangkau sejumlah besar orang. Media massa sering digunakan untuk komunikasi dua arah, yaitu media massa ke arah masyarakat dan masyarakat ke arah media massa.

Sebagai bentuk komunikasi, media massa menjadi alat vital dalam kehidupan masyarakat. Bahkan, media massa dituduh sebagai alat komunikasi yang tidak hanya berfungsi sebagai sumber informasi, melainkan sebagai alat pencipta realitas sosial. Malinda (2011:1) menyatakan bahwa media dan teknologi informasi telah menjadi salah satu faktor kunci dari dinamika budaya yang terjadi pada era globalisasi ini. Tak hanya itu, media massa dinyatakan dapat memberikan ilusi dan fantasi yang mungkin belum pernah terpenuhi lewat saluran-saluran komunikasi tradisional lainnya (Idi Subandi, 2011:85). Dari paparan tersebut, dapat disimpulkan bahwa media massa merupakan media yang mampu memberikan bias kepada masyarakat. Di satu sisi, media massa menciptaan realitas namun di sisi yang lain media memberikan ilusi dan fantasi. Dinamika media massa tak pelak memberikan dampak-dampak kepada masyarakat.

Salah satu hal yang kemudian dibawa oleh media massa adalah proses sosialisasi tentang berbagai isu yang ada di masyarakat. Salah satu isu yang sering disosialisasikan oleh media massa adalah isu gender. Sunarto (2004:113) menyatakan bahwa media massa seringkali memuat pemberitaan, kisah fiksi, maupun iklan yang menunjang 
stereotipe tentang gender. Media massa yang nampak paling menonjol dalam sosialisai gender adalah dalam periklanan.

Dalam periklanan, isu gender nampak dari perbedaan kegiatan antara laki-laki dan perempuan. Perempuan digambarkan sebagai manusia yang selalu peduli dengan rumah tangga dan penampilan fisik sedangkan laki-laki lebih peduli terhadap pekerjaan dunia bisnis, olahraga, mobil, dsb. Laki-laki digambarkan sebagai sosok yang pemberani, jantan, mandiri, kuat, tegar, berkuasa, pintar, dan rasional sedangkan perempuan digambarkan sebagai sosok yang lemah, emosional, bodoh, dan dikaitkan dalam hubungannya dengan laki-laki atau untuk menyenangkan laki-laki (Mulyana, 2008:82). Tak hanya itu, perempuan juga digambarkan secara fisik sebagai wanita yang berkulit putih dan mulus. Bahkan, kecantikan perempuan Indonesia digambarkan seperti kecantikan perempuan Korea (Sari, 2015:198).

Perkembangan jaman dan pola pikir saat ini menggeser paradigma tentang citra perempuan tersebut. Terbukti dari beberapa iklan yang temui penulis menggambarkan sosok perempuan sebagai perempuan yang tidak hanya cantik tapi juga pintar dan banyak terlibat dalam kegiatan di luar seperti bekerja, berbisnis, dan berolahraga seperti laki-laki. Atas dasar itu, penulis tertarik untuk meneliti mengenaiperbandingan stereotipe gender pada dua iklan yang memiliki jarak waktu produksi yang berbeda, yaitu tahun 2012 dan 2018.

Penelitian mengenai media massa dan gender telah dilakukan oleh beberapa peneliti. I Dewa Ayu Sugiarica Joni dalam tesisnya yang berjudul "Konstruksi Citra Perempuan di Media Massa: Analisis Semiotik terhadap Pencitraan Perempuan dalam Iklan Televisi" memperoleh beberapa temuan penelitian. Dari hasil analisis yang dilakukan oleh Joni, diperoleh kesimpulan bahwa citra perempuan di Indonesia oleh iklan ditempatkan sebagai pilar dalam urusan rumah tangga, pesolek atau suka berdandan, pemikat laki-laki, dan kedudukannya second class.

Penelitian lain yang berkaitan dengan tema yang penulis angkat adalah penelitian yang dilakukan oleh Febrimarani Malinda dengan judul karyanya "Konstruksi Makna Perempuan Dalam Iklan Televisi (Analisis Semiotika R. Brathes pada Iklan Televisi AXE Versi Harga Minim)". Dari hasil penelitian memperlihatkan iklan "AXE" mengkonstruksi perempuan sebagai karakter yang menyukai hal-hal yang bersifat minim. Perempuan membawa pesan produk melalui penonjolan fisik tubuh dan kecantikan. Hal ini merupakan pembentuk ideologi gaya hidup, identitas perempuan serta kelas sosial dalam sistem patriakhi. Hal ini merupakan hasil dari konstruksi media iklan televisi atas pemaknaan perempuan di dalam iklan produk laki-laki.

Penelitian lainnya adalah penelitian berjudul "Representasi Kecantikan Perempuan dalam Iklan" karya Rina Wahyu Winarni tahun 2015. Hasil penelitian menunjukkan bahwa kecantikan wanita dimaknai mempunyai wajah putih, langsing dan berambut lurus.

Penelitian sejenis lainnya adalah penelitian dari Ardiyanti Pradhika Putri dengan judul "Representasi Citra Perempuan dalam Iklan Shampoo Tresemme Keratin Smooth di Majalah Femina" pada tahun 2014. Hasil penelitian menunjukkan bahwa perempuan 
harus selalu tampil dengan tubuh yang ideal. Gambaran kecantikan yang ditampilkan membentuk pemikiran bahwa perempuan harus tampil cantik.

Penelitian yang telah dilakukan oleh peneliti terdahulu memberikan inspirasi kepada penulis untuk mengkaji lebih mendalam mengenai stereotipe gender pada dua iklan yang memiliki jarak waktu selama 8 tahun dalam proses produksinya.

Kajian yang akan digunakan dalam penelitian ini adalah kajian semiotika Roland Barthes. Penulis menggunakan metode semiotika karena ini model penelitian barakar dari paradigma konstruksi sosial, terutama media massa (Sobur, 2003:Vii).

\section{METODE PENELITIAN}

Kajian mengenai strereotipe gender dikaji dengan penelitian kualitatif dan analisis semiotika. Penelitian kualitatif adalah penelitian yang memusatkan penelitian pada pemecahan suatu masalah, data yang diperoleh berupa data tuturan atau kata-kata tertulis (Moleong, 2018:3). Penelitian deskriptif dipilih karena data yang diperoleh akan dideskripsikan dengan kata-kata. Penelitian ini bertujuan untuk memahami perbandingan stereotip gender pada dua iklan.

Data yang terdapat dalam penelitian ini adalah data kualitatif, yaitu data berupa deskripsi verbal dan nonverbal dari dua iklan yang dianalisis. Iklan pertama yaitu iklan Kecap ABC versi Suami Sejati Mau Masak diberi kode data ABC dan iklan Extra Joss versi Laki diberi kode data EJL. Teknik pengumpulan data dilakukan dengan dokumentasi dan observasi. Dokumentasi adalah suatu metode pengumpulan data yang sumber datanya berasal iklan yang ada di Youtube atau televisi. Video iklan tersebut dipotong menjadi beberapa gambar kemudian ditranskipsikan sehingga terbentuk sebuah naskah tertulis. Metode lainnya yang digunakan adalah dengan observasi partisipan, yaitu peneliti melakukan pengamatan terhadap iklan tetapi tidak terlibat dalam pembuatan iklan. Peneliti hanya mengamati kemudian menjelaskan hasil pengamatan terhadap fenomena gender dalam masyarakat. Analisis data dilakukan dengan metode intepretatif dan FGD. Penyajian analisis data dilakukan secara informal yaitu dengan menggunakan kata-kata yang mudah dipahami.

\section{PEMBAHASAN}

Stereotipe tentang gender merupakan wacana yang sangat menarik. Stereotipe gender terjadi pada berbagai hal. Salah satu yang paling banyak adalah terjadi pada dunia periklanan. Seperti yang telah dipaparkan sebelumnya, terdapat dua iklan yang dianalisis, yaitu iklan ABC yang menggunakan model laki-laki, perempuan, dan seorang anak sebagai tokoh utama dan iklan minuman EJL yang menggunakan model laki-laki sebagai tokoh utamanya. Pada kedua iklan ini, stereotipe gender akan dianalisis dengan teori semiotika Roland Barthes, yang memiliki tiga kode, yaitu makna denotasi, makna konotasi, dan mitos. Makna denotatif adalah makna yang mengacu langsung pada objek, makna konotatif adalah makna yang tersembunyi di balik makna denotatif, dipengaruhi oleh sistem yang ada (Barthes, 1964:90). Selain dua kode ini, juga ada kode mitos yaitu pengkodeean makna dan nilai-nilai sosial yang dianggap alamiah dengan 
menempatkan mitos sebagai makna terdalam dan bersifat konvensional (Rahayu, 2017:98).

\section{Makna Denotasi}

Makna denotasi adalah makna yang paling nyata dari sebuah tanda. Berikut ini merupakan perbandingan iklan ABC dan EJS ditinjau dari makna denotasi yang muncul dari iklan.

Tabel Perbandingan Makna Denotasi pada iklan ABC dan EJL

\begin{tabular}{|c|c|c|c|}
\hline \multicolumn{4}{|c|}{ Perbandingan Makna Denotasi Iklan } \\
\hline Iklan ABC & Makna Denotasi & Iklan EJL & Makna Denotasi \\
\hline 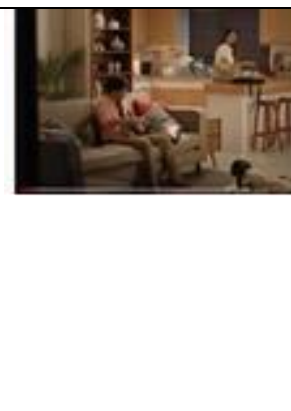 & $\begin{array}{l}\text { Seorang ayah } \\
\text { berbaju kantor, } \\
\text { berdasi, dengan } \\
\text { wajah lesu } \\
\text { mengeluh capek dan } \\
\text { duduk di sofa. }\end{array}$ & & $\begin{array}{l}\text { Beberapa pekerja } \\
\text { bangunan sedang } \\
\text { melaksanakan } \\
\text { aktivitas bekerja } \\
\text { dengan } \\
\text { backsound suara } \\
\text { perempuan dan } \\
\text { musik yang } \\
\text { mendayu-dayu. }\end{array}$ \\
\hline 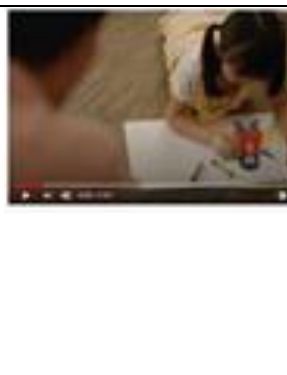 & $\begin{array}{l}\text { Seorang anak } \\
\text { perempuan } \\
\text { menggambar } \\
\text { pahlawan super } \\
\text { bunda }\end{array}$ & & $\begin{array}{l}\text { Para pekerja } \\
\text { berusaha } \\
\text { membengkokan } \\
\text { besi namun gagal } \\
\text { karena minuman } \\
\text { yang diminum } \\
\text { tidak tepat untuk } \\
\text { laki-laki. }\end{array}$ \\
\hline $\cos 1,8$ & $\begin{array}{l}\text { Ayah menghampiri } \\
\text { ibu dan membantu } \\
\text { ibu memasak di } \\
\text { dapur. }\end{array}$ & & $\begin{array}{l}\text { Para lelaki } \\
\text { berhasil } \\
\text { membengkokkan } \\
\text { besi karena } \\
\text { minum Extra } \\
\text { Joss. Suara } \\
\text { berubah menjadi } \\
\text { suara laki-laki } \\
\text { tulen. }\end{array}$ \\
\hline
\end{tabular}

Makna denotasi yang muncul dari dua iklan di atas adalah penggambaran laki-laki dan perempuan dalam iklan. Pada iklan ABC dan iklan EJL digambarkan tentang lakilaki yang sama-sama bekerja. Pada iklan ABC, model laki-laki mengenakan baju kemeja berwarna orange dengan dasi dan celana berwarna coklat. Tak lupa model lakilaki tersebut membawa tas dengan warna yang senada dengan celananya. Model lakilaki pada iklan $\mathrm{ABC}$ terlihat berambut rapi dengan wajah yang terlihat bersih meskipun raut mukanya terlihat capek. Berbeda dengan iklan ABC, pada iklan EJL terlihat beberapa model lelaki yang sedang berkerja di proyek bangunan. Para pekerja laki-laki ini mengenakan seragam berwarna putih dan bertopi. Wajah para model terlihat capek dan berkeringat karena pekerjaan lapangan di waktu siang hari yang sangat terik. 
Penggambaran perempuan pada iklan $\mathrm{ABC}$ adalah seorang perempuan atau ibu yang juga mengenakan baju rapi berwarna putih dan bawahan rok hitam. Model perempuan tersebut terlihat cantik dan masih segar meskipun pulang dari bekerja di kantor. Hal ini membuat anak perempuannya merasa sangat bangga dan menggambarkan super bunda karena kekuatan Bunda bisa bekerja dan memasak. Berbeda dengan iklan ABC, pada iklan EJL penggambaran perempuan tidak implisit terlihat karena hanya menggunakan suara perempuan sebagai backsound saat para pekerja laki-laki mengeluh panas dan capek saat bekerja.

\section{Makna Konotasi}

\begin{tabular}{|c|c|c|c|}
\hline \multicolumn{4}{|c|}{ Perbandingan Makna Konotasi Iklan } \\
\hline Iklan ABC & Makna Konotasi & Iklan EJL & Makna Konotasi \\
\hline 7 & $\begin{array}{l}\text { Pekerjaan ayah di } \\
\text { luar rumah (kantor) } \\
\text { menyita banyak } \\
\text { tenaga membuat } \\
\text { ayah merasa capek. }\end{array}$ & & $\begin{array}{l}\text { Pekerjaan lapangan } \\
\text { adalah pekerjaan } \\
\text { berat karena } \\
\text { menghabiskan } \\
\text { tenaga apalagi di } \\
\text { waktu siang hari } \\
\text { yang panas }\end{array}$ \\
\hline wann & $\begin{array}{l}\text { Perempuan adalah } \\
\text { pahlawan bagi } \\
\text { anaknya karena } \\
\text { bisa melakukan } \\
\text { segala hal seperti } \\
\text { bekerja dan } \\
\text { memasak. }\end{array}$ & & $\begin{array}{l}\text { Laki-laki tidak } \\
\text { akan bertenaga jika } \\
\text { mengkonsumsi } \\
\text { minuman yang } \\
\text { tidak khusus untuk } \\
\text { laki-laki }\end{array}$ \\
\hline 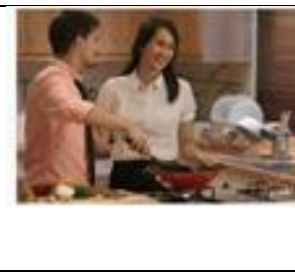 & $\begin{array}{l}\text { Ayah dan ibu bisa } \\
\text { saling membantu } \\
\text { memasak di dapur. }\end{array}$ & & $\begin{array}{l}\text { Laki-laki sejati } \\
\text { adalah laki-laki } \\
\text { yang kuat dan } \\
\text { mengkonsumsi } \\
\text { minuman yang } \\
\text { tepat. }\end{array}$ \\
\hline
\end{tabular}

Secara konotasi, perbandingan makna iklan ABC dan iklan EJL adalah bahwa bekerja di luar rumah bagi laki-laki adalah pekerjaan yang berat karena menyita banyak waktu, tenaga dan pikiran yang pasti membuat laki-laki merasa capek. Namun, saat menggambarkan perempuan terdapat perbedaan antara iklan ABC dan iklan EJL. Pada iklan ABC, perempuan digambarkan sebagai pahlawan super karena dapat bekerja dan memasak, walaupun bekerja bagi laki-laki adalah pekerjaan yang berat, perempuan memiliki kekuatan sehingga meskipun pulang bekerja tapi masih sanggup memasak. Pada iklan EJL, terjadi penggambaran sebaliknya, yaitu perempuan digambarkan sebagai makhluk lemah dengan adanya backsoud suara perempuan saat pakerja laki-laki merasa sangat capek dalam bekerja dan suara perempuan tersebut berganti dengan suara laki-laki yang mantap, kuat setelah para pekerja mengkonsumsi minuman yang membuat mereka bertenaga. 


\section{Perbandingan Mitos/Stereotipe Gander Iklan ABC dan Iklan EJL}

Setelah menganalisa makna denotasi dan makna konotasi dari iklan ABC dan EJL, kemudian dianalisa mitos dari kedua iklan tersebut. Mitos merupakan cara berpikir dari suatu kebudayaan tentang suatu cara mengkonseptualisasikan, atau memahami sesuatu (Rahayu, 2017:105). Mitos yang terkandung dari iklan ABC adalah persamaan gender antara laki-laki dan perempuan dalam kehidupan rumah tangga. Persepsi anak terhadap kedua orang tuanya dilihat dari kebanggaan anak kepada kedua orang tuanya yang bisa bekerjasama dalam kehidupan rumah tangga. Seorang Bunda yang bisa bekerja dan bisa memasak di dapur memberikan kebanggan kepada sang anak bahwa sang Bunda adalah seorang super bunda yang banyak memiliki kekuatan sedangkan seorang ayah yang bekerja namun merasa lelah dan tidak sehebat Bunda yang bisa memasak merepresentasikan bahwa laki-laki sebaiknya juga harus bisa memasak di dapur. Solusi dari pengiklan adalah adanya kecap ABC yang akan membantu ayah dapat memasak sehabat bunda yang memasak di dapur. Mitos yang terdapat pada iklan EJL adalah representasi citra laki-laki sebagai pekerja lapangan dengan tubuh yang gagah, kuat, dan berotot. Pada iklan EJL terdapat perbedaan gender antara laki-laki dan perempuan. Pada iklan EJL, suara perempuan yang muncul dengan suara backsound yang mendayu-dayu mencitrakan perempuan sebagai seseorang yang lemah, tak berdaya, dan mudah lelah. Pengiklan menonjolkan produk minuman dengan membandingkan minuman rasa-rasa dengan minuman laki. Minuman laki yang seharusnya adalah minuman yang bisa membuat seseorang bergairah, bersemangat, dan kuat dalam bekerja, bukan minuman rasa-rasa yang identik dengan minuman para perempuan. Pada iklan ini, terlihat stereotip gender dengan pandangan budaya patriaki. Patriaki dapat dipandang sebagai suatu hubungan sosial dimana kaum laki-laki mendominasi, mengeksploitasi dan menindas kaum perempuan. Sebagai sebuah konsep, patriaki mendefinisikan berbagai relasi tidak setara antar gender, meskipun harus memperhatikan kenyataan bahwa tidak semua laku-laki atau perempuan diuntungkan atau dirugikan (Winata, 2012: 48)

Berdasarkan dua iklan tersebut terdapat perbedaan yang jelas mengenai bagaimana iklan mengkonstruksikan gender. Stereotipe gender dalam iklan televisi telah menjadi topik perdebatan karena bias gender akan mempengaruhi cara berpikir tentang peran gender dalam masyarakat (Astuti, 2016). Iklan Extra Joss yang tayang terlebih dahulu yaitu 5 tahun sebelum iklan ABC menunjukkan konstruksi yang berbeda antara laki-laki dan perempuan. Jika pada tahun 2013, laki-laki digambarkan sebagai seorang yang kuat, tak kenal lelah, pekerja keras, tangguh sedangkan perempuan identik dengan makhluk lemah, lemas, dan tidak giat. Hal ini senada dengan pernyataan Mulyana pada tahun 2008 yang menyatakan bahwa dalam periklanan, isu gender nampak dari perbedaan kegiatan antara laki-laki dan perempuan. Perempuan digambarkan sebagai manusia yang selalu peduli dengan rumah tangga dan penampilan fisik sedangkan lakilaki lebih peduli terhadap pekerjaan dunia bisnis, olahraga, mobil, dsb. Laki-laki digambarkan sebagai sosok yang pemberani, jantan, mandiri, kuat, tegar, berkuasa, pintar, dan rasional sedangkan perempuan digambarkan sebagai sosok yang lemah, 
emosional, bodoh, dan dikaitkan dalam hubungannya dengan laki-laki atau untuk menyenangkan laki-laki (Mulyana, 2008:82).

Gambaran berbeda terlihat pada 5 tahun setelahnya yaitu pada iklan kecap ABC. Berbanding terbalik dengan iklan sebelumnya, iklan ini menggambarkan kesuperioran perempuan dalam kedudukannya. Perempuan digambarkan sebagai sosok yang sempurna bak pahlawan super yang bisa melakukan segala pekerjaan. Bekerja di luar rumah untuk mendapatkan uang namun juga tak melupakan kondratnya untuk melaksanakan kewajiban dalam urusan domestik. Hal ini juga disampaikan dalam artikel Ummi Hanifah yang menjelaskan bahwa perbedaan antara ruang publik dan ruang privat sifatnya tidak baku tetapi hanya orientasi tujuan dimana laki-laki berada di sektor publik sementara perempuan di sektor domestik. Namun, perempuan juga harus memiliki hak yang sama dalam memperoleh pendidikan dan berkiprah dalam masyarakat (Hanifah, 2011: 199-220).Menurut Erving Goffman, ada hubungan yang kuat antara iklan dengan realitas, atau setidaknya antara iklan dengan ritual dalam masyarakat. Iklan akan selalu mencari strategi agar pesan-pesan yang ingin disampaikan kepada khalayak bisa diterima dan dimengerti. Pada umumnya dalam sebuah iklan akan menggunakan bahasa, citra-citra, gagasan-gagasan dan nilai-nilai yang ditarik dari budaya dimana pengiklan maupun khalayak menjadi produk dari budaya tersebut. Sebagaimana Berger dan Luckman menyakini secara subtantif bahwa realitas merupakan ciptaan manusia kreatif melalui kekuatan konstruksi sosial terhadap dunia di sekelilingnya (Malinda, 2011:79). Iklan merupakan agen sosial yang paling berpengaruh dewasa ini. Stereotipe gender dibawa lewat pesan-pesan simbolik yang terdapat pada iklan. Steretotipe ini semakin menguat di masyarakat karena didukung oleh sistem sosial yang kondusif. Di samping itu, citra hitam putih tentang streotipe perempuan dan laki-laki mengalami proses sosialisasi secara terus menerus dari generasi ke generasi melalui beberapa agen sosial sistemik. Dalam menggambarkan pola hubungan atau relasi antara laki-laki dan perempuan televisi saat ini dianggap mampu menyuguhkan ide kesetaraan gender sebagaimana yang dikehendaki oleh para aktifis feminis dan pemerhati masalah perempuan. Steotetipe yang dianggap cenderung menguntungkan kaum perempuan yang dimunculkan dalam media televisi terutama dalam iklan yang menggambarkan bahwa perempuan itu aktif, tidak tergantung pada laki-laki.

\section{KESIMPULAN}

Stereotipe gender yang dibawa media massa khususnya pada iklan merupakan bentuk dari sosialisasi yang terus menerus. Iklan yang dikaji pada penelitian ini adalah dua iklan yang diasumsikan oleh peneliti menunjukkan adanya stereotipe gender yaitu iklan makanan kecap ABC versi Suami Sejati Masak dan iklan minuman "Extra Joss". Analisis yang dilakukan pada penelitian ini menggunakan analisis semiotika Roland Barthes. Dari hasil analisis dapat disimpulkan bahwa pada kedua iklan ini menunjukkan stereotipe gender, yaitu perbedaan penggambaran antara iklan pada tahun 2013 dan iklan pada tahun 2018. Perbedaan tersebut terdapat pada penggambaran citra perempuan. Jika pada iklan Extra Joss yang tayang pada tahun 2013 digambarkan 
bahwa seorang perempuan adalah sosok yang memiliki karakter pemikat laki-laki, pesolek, lemah, dan tidak memiliki semangat untuk bekerja keras. Sebaliknya, sosok laki-laki adalah sosok yang memiliki karakter kuat, dan mampu bekerja keras. Hal berbeda digambarkan pada iklan tahun 2018 yaitu iklan Kecap ABC yang mengkonstruksikan persamaan gender antara laki-laki dan perempuan bahwa perempuan adalah sosok yang kuat dan pekerja keras serta dapat menyeimbangkan kehidupan antara bekerja di luar rumah dengan pekerjaan domestik. Sedangkan laki-laki juga memiliki sisi lemah yaitu dapat bekerja di luar rumah untuk mencari nafkah namun tidak bisa mengurusi urusan domestik. Proses stereotipe gender yang dibawa oleh iklan merupakan bentuk konstruksi sosial. Hal yang digambarkan pada iklan memberikan pengaruh kepada masyarakat luas tentang pelabelan antara karakter dari laki-laki dan perempuan

\section{UCAPAN TERIMA KASIH}

Ucapan terima kasih kepada DRPM Ristekdikti, P2M IKIP Budi Utomo Malang yang telah memberikan dana untuk penelitian dosen pemula tahun anggaran 2020.

\section{DAFTAR RUJUKAN}

Astuti, Y. D. (2016). Media dan Gender (Studi Deskriptif Stereotip Perempuan dalam Iklan Televisi Swasta. Profetik, 25-31.

Barthes, R. (1964). Elements de Semiologie atau Elemens of Semiologi, terjemahan Annete Lavers dan Colin Smith. New York: Hill and Wang.

Hanifah, U. (2011). Konstuksi Ideologi Gender pada Majalah Wanita (Analisis Wacana Kritis Majalah UMMI . Jurnal Dakwah dan Komunikasi, 199-220.

Joni, I Dewa Ayu Sugiarica. (2009). Konstruksi Citra Perempuan di Media Massa: Analisis Semiotik terhadap Pencitraan Perempuan dalam Iklan Televisi. Tesis, tidak diterbitkan. Yogyakarta: Universitas Gadjah Mada.

Malinda, Febrimarani. (2011). Konstruksi Makna Perempuan Dalam Iklan Televisi (Analisis Semiotika R. Brathes pada Iklan Televisi AXE Versi Harga Minim). Tesis, tidak diterbitkan. Yogyakarta: Universitas Gadjah Mada.

Moleong. (2018). Metodologi Penelitian Kualitatif. Bandung: Remaja Rosdakarya. Mulyana, D. (2008). Komunikasi Massa:Kontroversi, Teori, dan Aplikasi. Bandung:

Widya Padjajaran.

Putri, A.P. (2014). Representasi Citra Perempuan dalam Iklan Shampoo Tresemme Keratin Smooth di Majalah Femina. Jurnal Komunikasi, 134-152. 
Rahayu, U.N dan Alfrianto, D.T. (2017). Representasi Citra Laki-Laki dalam Iklan Gatsby Styling Pomade Kajian Semiotika Roland Barthes. Jurnal Media Seni Rekam. 93-107.

Sobur, A. (2002). Analisis Teks Media: Suatu Pengantar Untuk Analisis Wacana, Analisis Semiotik, dan Analisis Framing. Bandung: Rosda Karya.

Sunarto, K. (2004). Pengantar Sosiologi Edisi Revisi. Jakarta: Universitas Indonesia.

Sari, W. P. (2015). Konflik Budaya dalam Konstruksi Kecantikan Wanita Indonesia (Analisis Semiotika Dan Marxist Iklan Ponds Wahite Beatuty Versi Gita Gutawa. Jurnal Komunikasi, 198-206.

Winata, I. N. (2012). Hegemoni Maskulinitas dalam Iklan Minuman Berenergi (Analisis Semiotika TVC Extra Joss dan Kuku Bima Energi-G). Jurnal Ilmiah Komunikasi Makna, Vol.3 No.1, 42-49.

Winarni, R. W. (2010). Representasi Kecantikan Perempuan dalam Iklan. Deiksis, 134152. 